\title{
Исследование процессов обработки
}

UDC 621.9.011:669.131.2

\author{
L. Chen ${ }^{1, *}$, J. Persson ${ }^{2}$, J. E. Ståhl' ${ }^{2}$, J. M. Zhou ${ }^{2}$ \\ ${ }^{1}$ School of manufacturing science and engineering, \\ Sichuan University, Chengdu, China \\ ${ }^{2}$ Division of production and materials engineering, Lund University, \\ Lund, Sweden \\ *chenlingscu@scu.edu.cn
}

\section{Nano-scratching resistance of high-chromium white cast iron and its correlation with wear of $\mathrm{cBN}$ tool in machining}

In this paper, a nano-scratch testing approach was used to measure and evaluate the abrasion wear resistance of high-chromium white cast irons in order to understand the wear mechanism in the interaction between the high-chromium white cast iron and the cBN cutting tool during the machining process. Scratch testing was performed on a nanoindentation instrument using a diamond indenter as the scratch tool. Linear multi-pass scratches in the same path were made on pre-worn surfaces of test materials. The correlation of the scratching resistance and tool wear measured from the machining is presented by the flank wear and maximum scratch depth. The appearance of the cutting edge on a $c B N$ tool suggests that the abrasion wear is mainly related with a combined effect of the carbides and the matrix during machining the high-chromium white cast iron.

mechanism, $c B N$

Keywords: scratch test, high-chromium cast iron, fracture, wear

\section{INTRODUCTION}

High-chromium white cast iron (HCCI) has exclusive properties in wear resistance due to the substantial presence of chromium-rich carbides, which makes it suitable for a wide range of applications in the mining industry. Machinability of the HCCIs is strongly influenced by their microstructure and microscale mechanical properties or the material abrasiveness. Factors such as grain size of carbides, phases, and wear resistance properties play important roles and determine the extent of tool wear, stability, and surface quality during machining [1]. From the previous studies, the high hardness $\left(500 \mathrm{H}_{B}\right)$ of the matrix and imbedded cementite $\left(\mathrm{Fe}_{3} \mathrm{C}\right)$ formed at the rapid cooling rate during the casting process caused the high abrasion wear resistance and a rapid cutting tool 
deteriorations, such as cutting tools of pcBN (polycrystalline cubic Boron Nitride) [2]. This leads to the generally low production efficiency and high production cost.

The abrasion resistance of these materials is profoundly influenced by the microstructure and micromechanical properties of the material. The performance of HCCI materials can be improved by a heat treatment [3] and changes of the composition $[4,5]$. The composition of the matrix phase can be suitably modified to achieve a proper balance between the resistance to abrasion and the toughness needed to withstand a repeated impact [6]. However, the wear performance of the material is very hard to evaluate for the wide variety of acceptable wear test, which can give the significantly different results depending on the different conditions and parameters from the test. In this study, an attempt has been made to understand the effect of metallurgical factors such as the morphology and volume fraction of carbides as well as wear resistance properties of the machinability of the materials. The microstructures of HCCI materials with different compositions (carbon and silicon contents) have been characterized under the as-cast as well as annealed and hardened conditions using scanning electron microscopy, Nano-scratching and machining techniques.

\section{MATERIAL PREPARATION}

The HCCI is virtually a composite material, which includes a metallic matrix and is reinforced with carbide particles. The minor change of chemical composition and heat treatments are applied to modify the composition of the matrix phase to achieve different wear resistance performance of the material. In this study, two groups of high-chromium cast irons were prepared, with the chromium content of $25.7 \mathrm{wt} \%$. The group with lower C-Si content had $2.71 \mathrm{wt} \%$ $\mathrm{C}$ and $0.8 \mathrm{wt} \% \mathrm{Si}$ and the group with higher $\mathrm{C}-\mathrm{Si}$ content had $2.95 \mathrm{wt} \% \mathrm{C}$ and $1.47 \mathrm{wt} \% \mathrm{Si}$. The alloys were cast into rounds $(66 \mathrm{~mm}$ in diameter) and cut to pieces of $10 \times 10 \times 5 \mathrm{~mm}^{3}$ using a wire electrical discharge machine. The groups were divided on the basis of carbon-silicon $(\mathrm{C}-\mathrm{Si})$ contents. There are three samples per group, one corresponded to the as-cast condition, the other two to the annealed (heating to $930{ }^{\circ} \mathrm{C}$, holding time: $1.5 \mathrm{~h}$, cooling to $650{ }^{\circ} \mathrm{C}$, holding time: $1 \mathrm{~h}$, cooling to $600{ }^{\circ} \mathrm{C}$, holding time $2 \mathrm{~h}$, cooled to room temperature) and the hardened conditions (heating to $940{ }^{\circ} \mathrm{C}$, holding time $2 \mathrm{~h}$, quenched to room temperature). All the specimens were mounted, ground, and polished following standard metallographic procedure. The final polishing procedure was done $\mathrm{SiO}_{2}$ particles $(0.04 \mu \mathrm{m})$. The etchant in the test is a modified glyceregia [7].

The microstructures of the different samples are affected by the composition and heat treatments significantly, as presented in the previous research [8], one of the typical microstructure of as-cast sample is shown in Fig. 1. In all the samples, regardless of the initial composition, no significant change in the morphology of the eutectic carbide was observed after a heat treatment. The main transformation happened on the matrix. In the lower $\mathrm{C}-\mathrm{Si}$ group, the matrix of the as-cast sample contains the primary austenite dendrites with needle-like martensite; after the annealing procedure, the austenite and martensite are transformed to bainite in the matrix, and plenty of secondary carbides are observed in the matrix; in the procedure of hardening, the matrix is transformed to mixture of the martensite and finer size of secondary carbides, the volume and size of secondary carbides are smaller than the secondary carbides in the matrix of annealed sample. As the same, the transformation in the higher $\mathrm{C}-\mathrm{Si}$ group is also happened on the matrix only. The as-cast sample is bainite; annealed sample is a mixture of perlite and big size of secondary carbides, and hardened sample is a mixture of martensite and finer 
size of secondary carbides. The SEM images of 6 samples showed the influence of heat treatments on the microstructures and phase evolution in the samples in greater detail in the matrix.

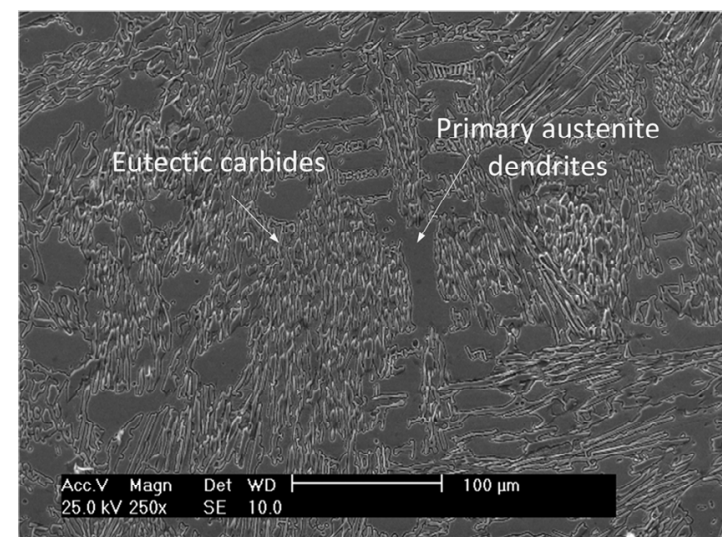

Fig. 1. Typical microstructure of HCCI material in lower C-Si group and as-cast condition.

\section{NANO-SCRATCHING TEST AND MACHINING SETUP}

The mechanical properties of the various phases such as hardness and wear resistance properties were determined from the tests. Experimental results from each scratch performed at random locations on the surface of a multiphase material can be presented as distance-depended plots of scratch depth and force. Multiple peaks in the plot of scratch depth correspond to the various phases in the material before the cracking of the carbides, and the cracking position showed the fracture properties of the carbides of the material. The test results were calibrated by a fused silica, and the detail procedure of the tribological properties analysis is presented in Fig. 2.

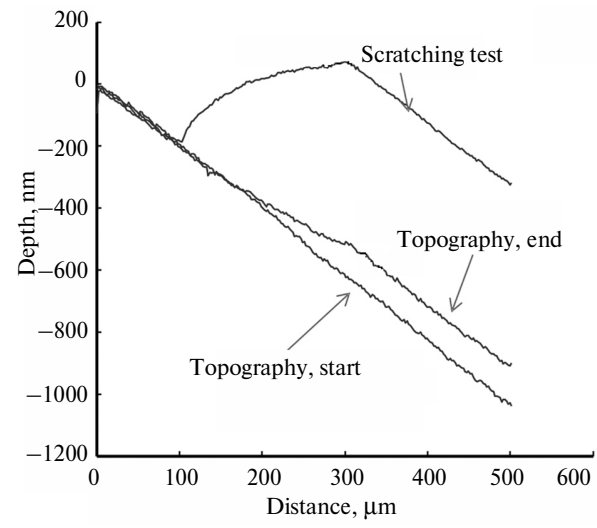

$a$

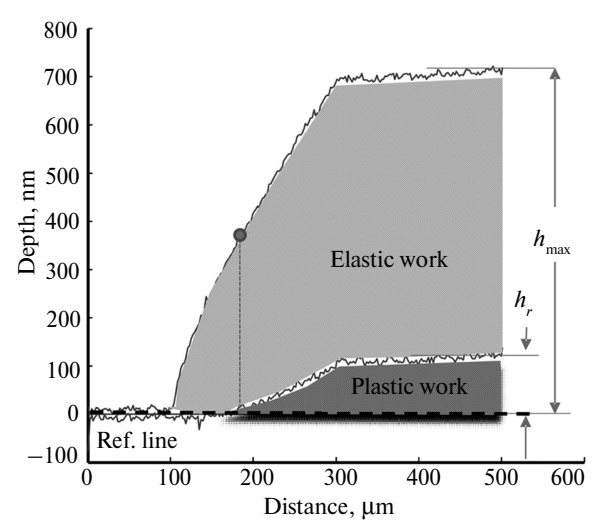

$b$

Fig. 2. The calibrated scratch test of fused silica sample by the load of $100 \mathrm{mN}$, test curve with topography effect $(a)$, the analytical curve by removing of topography effect $(b)$.

The scratch tests were performed on a NanoTest Vantage nanoindentation instrument with a loading range of 0.01 to $500 \mathrm{mN}$ and a conical diamond indenter. The abrasive wear of these samples was evaluated and compared using the Nanoscratch techniques under different loads. A damage caused by scratching was 
examined using depth-distance curves. The material pile-up took place in all scratched samples, but to different degrees. The presented results are based on the diamond conical indenter with $5-\mu \mathrm{m}$ tip radius, the effects of the composition and heat treatment on the overall wear behaviour at various loads are investigated. The other settings are shown in the table.

The test setup in nano-scratch

\begin{tabular}{c|c}
\hline Name & Value \\
\hline Scanning velocity, $\mu \mathrm{m} \cdot \mathrm{s}^{-1}$ & 10 \\
Scanning length, $\mu \mathrm{m}$ & 500 \\
Number of passes & 22 \\
Number of scratches per topography & 1 \\
Topography load, $\mathrm{mN}$ & 0.1 \\
Scratch load, $\mathrm{mN}$, is applied after $100 \mu \mathrm{m}$ & $10,100,200,300$ \\
Load rate, $\mathrm{mN} \cdot \mathrm{s}^{-1}$ & 5 \\
\hline
\end{tabular}

The scratched surface was significantly different for two groups with different heat treatment conditions. It was found that the wear resistance of HCCI samples does not follow the classical theory; the wear resistance is not linearly proportional to the hardness. This discrepancy was suggested to being a result of different wear mechanisms operating in different materials.

Since the divergence in wear values is the wide variety of acceptable wear tests, which can give significantly different results depending on the test conditions such as sliding vs. abrasive wear (two or three bodies), sliding load and speed, and surface roughness. The method to assess the wear performance is compared the depth curves of all samples by the same load. The scratch test has done on the load of 10 and $300 \mathrm{mN}$ on the length of $500 \mu \mathrm{m}$. The $10 \mathrm{mN}$ has done on the multicycles of 20 times.

The scratched surfaces were significantly different for two groups with different heat treatment conditions. It was found that the wear resistance of HCCI samples does not follow the classical theory; the wear resistance is not linearly proportional to the hardness. This discrepancy was suggested to being a result of different wear mechanisms operating in different materials.

Since the divergence in wear values is the wide variety of acceptable wear tests, which can give significantly different results depending on the test conditions such as sliding vs. abrasive wear (two or three bodies), sliding load and speed, and surface roughness. The method to assess the wear performance compares the depth curves of all samples by the same load. The scratch test was done on the load of 10 and $300 \mathrm{mN}$ on the length of $500 \mu \mathrm{m}$. The $10 \mathrm{mN}$ was shown on the multi-cycles of 20 times.

In the test results, the curves are adjusted to horizontal way, and the removal of the topography effect of the initial surface, seen as Fig. 2, $a$. The scratching curve is only showing the deformation, and the residual deformation is presented as the end topography curve without the roughness effect. The start topography curve is presented as the reference line in Fig. 2, $b$. The final results are shown in Fig. 2, $b$. The pre-test is the topography measurement, and the follow is elastic deformation part for the yield stress evaluation. The plastic part shows the wear defect by the applied load. The friction coefficient is obtained from the stable part of the curve. Under the load of the $100 \mathrm{mN}$, the yield stress happened under the $400 \mathrm{~nm}$ depth, 
and the value is about $4.5 \mathrm{GPa}$. The value is matched with the reference value of fused silica. Because the size effect also existed in the test results, the presented study only presents the yield point on the specific load. The topography curve is applied to measure the residual deformation after the scratching, and the maximum depth is obtained from the scratching pass of the curve.

Since the wear performance of the material is very hard to evaluate for the wide variety of acceptable wear tests, which can give the significantly different results depending on the different conditions and parameters of the test. From the presented work, the conditions are controlled in humidity, temperature, roughness, and so on. The test parameters are evaluated by $h_{\max }$ and scratch load.

All machining tests were performed on a SMT500 turning center employing a continuously variable spindle speed up to a maximum of $4000 \mathrm{rpm}$ and a driver motor rated up to $75 \mathrm{kw}$. The selection of cutting parameters covers the range of industrial production and the recommendation from cutting tools manufacturer. Dry machining tests were conducted throughout the tests; the machining test setup is presented in the previous work [9]. Pre-cut was made on each workpiece before the tests in order to remove the rough out-layer from prior casting process and heat treatment. Flank wear on the cutting tool was measured by means of Alicona Infinite Focus optical microscope. The materials were cast into bar shapes with a diameter of $66 \mathrm{~mm}$ and a length of $370 \mathrm{~mm}$.

\section{RESULTS AND DISCUSSIONS}

The mechanical properties of various phases and their abrasion resistance properties were determined by the Nano-scratch approach. This technique is often used for measuring the fracture, wear, and friction behavior over a certain length on the surface of the material. It has the potential to extract the mechanical properties of the measured phases provided the load of scratch which is carefully chosen to minimize the influence of the surrounding medium [10].

The heat treatment and composition are significant for the wear performance of the HCCI in scratch tests. Linear multi-passes scratches in the same path were made on pre-worn surfaces. The results of the sequential multi-passes tests on the pre-worn surfaces showed that the heat treatment and composition affect the maximum scratch depth $\left(h_{\max }\right)$ in Fig. 3 by the load of 10 and $100 \mathrm{mN}$. In Figs. 3, $a-c$, the annealed samples have the highest maximum scratch depth $\left(h_{\max }\right)$ and the hardened samples have the lowest $h_{\max }$. In composition group (see Figs. $3, b-d$ ), the samples in higher $\mathrm{C}-\mathrm{Si}$ group showed the better wear resistance performance than corresponding samples in the lower $\mathrm{C}-\mathrm{Si}$ group.

Figure 3 shows that the hardened sample has the smallest scratch depth in the multi-cycles $10 \mathrm{mN}$ test and the increasing rate didn't changed too much; the ascast sample has the middle value and small increasing rate; but the annealed sample has the highest increasing rate in all samples in a composition group of lower $\mathrm{C}-\mathrm{Si}$, seen in Fig. 3, $a$. The results of the sequential multi-passes tests on pre-worn surfaces showed that a gradual enlargement of pre-existing cavities in primary carbides occurs by a fracture near the unsupported edges of the cavities. Figure $3, b$ shows that the lower $\mathrm{C}-\mathrm{Si}$ group has the similar scratch maximum depth with the higher $\mathrm{C}-\mathrm{Si}$ in as-cast condition. Under the load of $10 \mathrm{mN}$, the wear only happened on the matrix, the $h_{\max }$ of annealed sample in the lower $\mathrm{C}-\mathrm{Si}$ group showed the largest increasing rate in all samples. The $h_{\max }$ of as-cast sample in the higher C-Si group showed the larger increasing rate than the corresponding sample in the lower $\mathrm{C}-\mathrm{Si}$ group. 

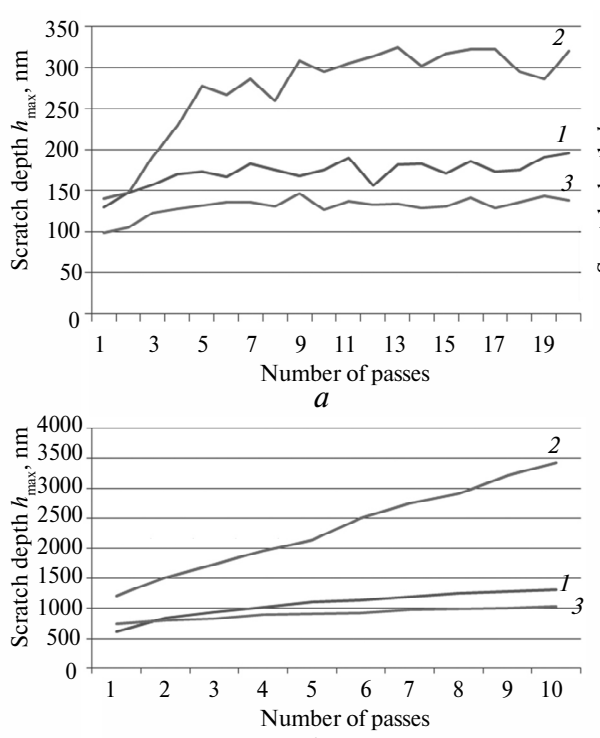

$c$
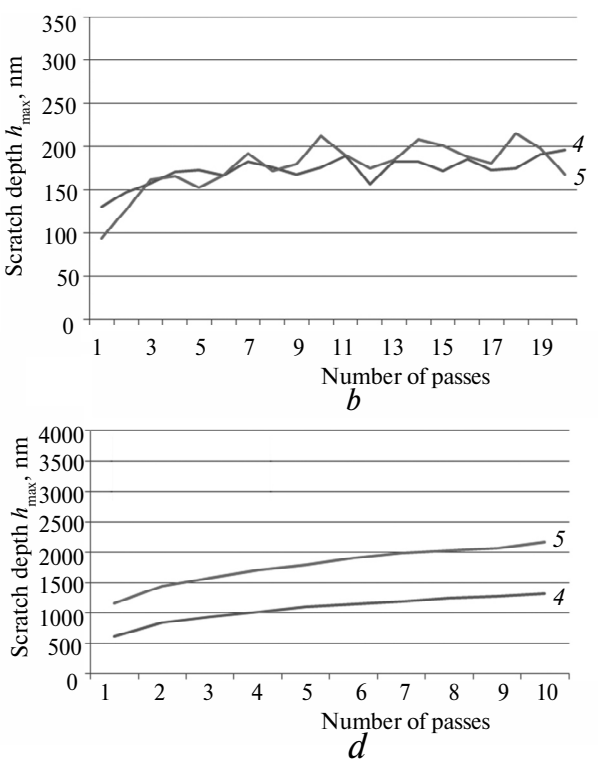

Fig. 3. The results of the sequential multi-passes tests on pre-worn surfaces: heat treatment effect by $10 \mathrm{mN}(a)$, composition effect by $10 \mathrm{mN}(b)$, heat treatment effect by $100 \mathrm{mN}(c)$, composition effect by $100 \mathrm{mN}(d)$ : as cast (1), annealed (2), hardened (3), lower C-Si (4), higher C-Si (5).

Once load of scratch increased to $100 \mathrm{mN}$, the wear performance is abrasive wear by the linear increasing of the maximum depth with the test number. Figure 3 , $c$ showed the hardened sample has the best wear resistance performance in the multi-passes by $100 \mathrm{mN}$ test. Figure $3, d$ showed that the $h_{\max }$ of as-cast sample in higher $\mathrm{C}-\mathrm{Si}$ group has the higher $h_{\max }$ than the corresponding sample in lower $\mathrm{C}-\mathrm{Si}$ group. After 10 passes of scratch tests, the $h_{\max }$ is higher $3.5 \mu \mathrm{m}$ in annealed sample, and this height is larger than the half of the average grain size of carbides, and the particle is possibly removed from the matrix. The cracking and fracture are increasing with the increasing load and number of passes. Based the above results, the wear resistance performance is not depend only on the carbides' type and volume fraction; it is also related to the matrix hardness and hardness distribution.

With the increasing number of scratches passes, the softer hardness of the matrix has the larger wear volume. The annealed sample in the lower $\mathrm{C}-\mathrm{Si}$ group has the largest scratch depth in the matrix for the smallest matrix hardness $(3.2 \mathrm{GPa})$. With the increased wear test numbers, it showed the largest increasing rate of $h_{\max }$ with the increased test number in annealed sample. This means the annealed sample has the largest wear volume and worst wear resistance performance, the carbides in the annealed samples are easy to be removed from the soft matrix and caused the fatigue wear. In total, the scratch depths and the depths different are directly related the phase hardness.

From the multi-passes scratches tests, the hardened sample has the smallest $h_{\max }$ and caused smallest wear volume. In the comparison of the heat treatments in two groups, hardened samples have the smallest wear volume, and largest wear volume in annealed sample for the highest volume fraction. Under the load of $10 \mathrm{mN}$, the abrasive wear related to the hardness and volume fraction of the matrix. The maximum scratch depth $\left(h_{\max }\right)$ is affected by the hardness of phases of the material. Due to the similar hardness of the carbides in each composition group, the higher hardness of the matrix has the lower $h_{\max }$ in the scratch tests. 
The composition effect of $\mathrm{C}$ and $\mathrm{Si}$ showed that the as-cast sample in lower $\mathrm{C}-\mathrm{Si}$ has the better wear resistance performance. With the increased silicon in the material, the volume of carbides in increased and improved the hardness distribution of carbides, the results are presented in the previous work [8]. However, the silicon is also improved the bainite transformation in the matrix and increased the $h_{\max }$ in the higher silicon group. Gross carbide fracture was not produced during scratch testing even though the loads used were considerably in excess of those experienced during low-stress abrasion.

As-cast sample in the higher $\mathrm{C}-\mathrm{Si}$ group is applied to study the relationship of the wear performance with the increased loads. The abrasive wear is performed by the straight grooving on the surface by the load of $100 \mathrm{mN}$. At the load of $200 \mathrm{mN}$, the grooving is not straight for the deformation of carbides. The two curves are different for the cracking at the length about $300 \mu \mathrm{m}$ and generated the higher depth. After the load of $300 \mathrm{mN}$, the serious cracking and damage happened for the different deformation of discontinuous carbides and matrix in the scratch tests. The difference deformation between matrix and carbides is increasing with the increased loads, and the recovering force generates the high side force and bent the groove line from scratch. The rounding of carbides was shown to be due to a micro-fracture of the sharp carbide edges left unsupported by the matrix. Scratch tests on pre-worn surfaces produced no grooves on the carbides even at high loads, and the matrix between the carbides was protected by the protruding carbides. The results showed the hardness and hardness distribution in matrix of as-cast sample in higher $\mathrm{C}-\mathrm{Si}$ group are very important to support the carbides of the material, and improve the wear performance.

Since the different load has the different scratch depth, the load effect on different samples is difficult to compare directly. The relative value is used to evaluate the wear performance of the materials. The relative value is defined by the data compared to mean in the percentage way, it is expressed as $k_{i}=y_{i} / \bar{y}$. The results are presented in Fig. 4. The $h_{\max }$ is stable changed with increased load. It means that the load shows little effect on the difference of $h_{\max }$. Due to the wear resistance of the materials is related to the wear depth in the materials. In this way, the $h_{\max }$ is suggested to represent the abrasiveness of the material.

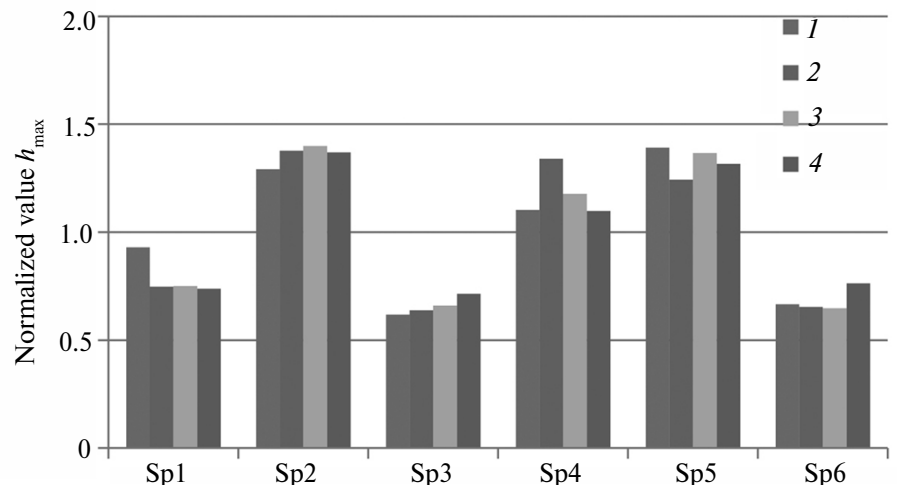

Fig. 4. Relative value of $h_{\max }$ represent wear performance features of HCCI materials by the load of $10(1), 100(2), 200(3), 300(4) \mathrm{mN}$.

Under the different loads, the $h_{\max }$ is only related with the hardness of the matrix, and little effect by the load. The hardened sample in the higher C-Si group (Sp 6) has the minimum value in all six samples for the highest carbide volume fraction by analysis of metallurgical and scratch testes. The annealed sample in the 
higher $\mathrm{C}-\mathrm{Si}$ group $(\mathrm{Sp} 5)$ has the maximum value for the softest matrix of pearlite. In the annealed sample of the lower $\mathrm{C}-\mathrm{Si}$ group $(\mathrm{Sp} 2)$ and the as-cast sample in the higher $\mathrm{C}-\mathrm{Si}$ group $(\mathrm{Sp} 4)$, the bainite has the larger work harden effect to strengthen abrasiveness properties of the material, so the abrasiveness value is higher than that of sample Sp 5. In the as-cast sample in lower C-Si group (Sp 1), the hard carbides are enhanced by the bound phase of austenite and martensite.

The composition group showed that the lower $\mathrm{C}-\mathrm{Si}$ group had the better wear resistance than the higher $\mathrm{C}-\mathrm{Si}$ group for the finer grain size of carbides with the same heat treatment. And the heat treatment changed the matrix hardness. Deformation of the scratch started the soft matrix firstly, which is proved by the low load of the scratch test. With the increased load, the material generated the cracking and finally deformed the carbides and generated the serious damage of the material. The wear resistance is related to the hardness of the matrix and carbides and their volume fraction. With the higher hardness of the matrix and higher volume fraction of the carbides, the sample has the better wear resistance. Scratch tests performed using fragments of carbide debris showed that carbide can cut through another carbide. It is proposed that the grooves which are produced in the leading edges of carbides during abrasion are caused by carbide debris.

Effect of the work materials on flank wear was shown in Fig. 5, $a$. Larger flank wear was found on the cutting tool after machining the lower $\mathrm{C}-\mathrm{Si}$ material in comparison to the flank wear obtained after machining the higher $\mathrm{C}-\mathrm{Si}$ material. This could be explained by its higher hardness of matrix in the lower C-Si material than higher $\mathrm{C}-\mathrm{Si}$ material. In lower $\mathrm{C}-\mathrm{Si}$ material, the main part of the matrix is formed by $52 \%$ of martensite, while the main part of the matrix in the higher $\mathrm{C}-\mathrm{Si}$ material is formed by bainite. The hardness of bainite is much lower than of martensite.

Figure 5, $a$ also reveals the effect of the cutting speeds on tool wear when two materials were tested. The tool wear was clearly influenced more by the cutting speed when lower $\mathrm{C}-\mathrm{Si}$ material was cut. The hardness of austenite could be increased as result of strain hardening at the higher shear rate in higher cutting speed, which reinforces the total hardness of matrix in this material. However, little influence on tool wear was found in the machining higher $\mathrm{C}-\mathrm{Si}$ material.

As mentioned in the above, high-chromium white cast iron is very abrasive material, causing be embedded hard carbides. The abrasiveness of the materials can be described by $h_{\max }$ from the scratch test, which is proportional to the amount of carbides, carbide hardness and the hardness difference between the carbide and matrix. Figure 5, $b$ reveals the correlation between $h_{\max }$ and flank wear of the cutting tool, which suggests that the wear of the cutting tool generated during machining of the high-chromium white cast iron is pre-dominated by abrasive wear and the $h_{\max }$ can to some extent predict the machinability of the work material in terms of the abrasive tool wear.

The wear resistance performance is tested from the different loads in HCCI materials, the deformation of the scratch is happened in the elastic deformation of the material, and in the softest matrix the plastic deformation happened firstly. With the increased load, the material generated the cracking and finally deformed the carbides of the material seriously. The wear resistance is related with the hardness of the matrix and carbides, and their volume fraction. With the higher hardness and higher volume fraction, the sample has the better wear resistance. From the increased flank wear with the increasing of $h_{\max }$, tool wear is mainly affected by the scratch resistance of the materials. The abrasion resistance measured by this method has been shown to correlate with $h_{\max }$ in scratch test response and with the performance of $\mathrm{cBN}$ tools in cutting tests. 

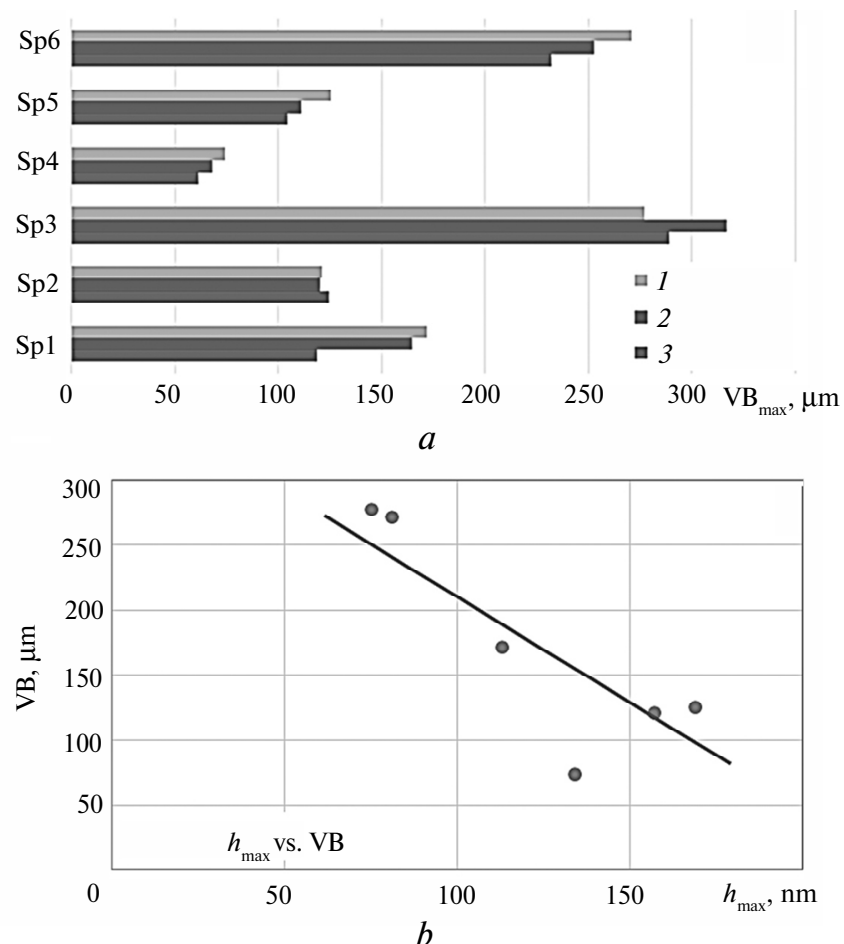

Fig. 5. Influence of materials on tool wear $(a)$ and the correlation of $h_{\max }$ with tool wear in machining $(b): v_{c}=120(1), 140(2), 160(3) \mathrm{m} / \mathrm{min}$.

\section{CONCLUSIONS}

Wear resistance of the HCCI materials were characterised with use of nanoscratch tests on a nanoindentation instrument. Types of carbide and correspondent volume fraction play a decisive role in the wear resistance of the test materials. The morphology of carbides and volume fraction are strongly affected by the chemical composition (carbon and silicon contents) as well as the heat treatment applied on them. With the increasing scratching load, the composition of the materials demonstrates a predominate effect in the wear resistance in comparison to the effect of heat treatment. The maximum scratch depth in nano-scratch test exhibited the good agreements with wear resistance performance of the HCCI materials.

The correlation of the scratching resistance and tool wear measured in machining is presented by the flank wear and maximum scratch depth. The appearance of the cutting edge on a cBN tool suggests that the abrasion wear is mainly related with combination effect of the carbides and the matrix during machining the high-chromium white cast iron. From the increased flank wear with the increasing $h_{\max }$, tool wear is mainly affected by the scratch resistance of the materials. The abrasion resistance measured by this method has been shown to correlate with $h_{\max }$ in scratch test response and with the performance of cBN tools in cutting tests.

\section{ACKNOWLEDGMENT}

This research is a part of the strategic research program the Sustainable Production Initiative SPI, cooperation between Lund University and Chalmers University of Technology. The author would like to thank the Xylem AB for providing the work materials and the financial support by the personnel start-up project (Grant Agreement No: YJ201642) of Sichuan University. 
Досліджено зносостійкість білих чавунів з високим вмістом хрому при використанні наноподряпання для того, щзоб зрозуміти механізм зношування при взаємодії високохромістого білого чавуну і різального інструменту з КБН під час процесу оброб$\kappa и$. Випробування наноподряпанням виконано на приладі для наноіндентування з використанням алмазного індентора. Лінійні багатопрохідні подряпини на одній і тій же діляниі було зроблено на попередньо зношених поверхнях матеріалів, що випробували. Кореляцію спротиву подряпанню $i$ зносу інструменту, виміряних при точіння, визначено при порівнянні зносу фальца і максимальної глибини подряпини. Зовнішній вигляд ріжучої кромки на інструменті з сBN дозволяе припустити, щзо абразивний знос матеріалу в основному пов'язаний з взаємодією карбідів $і$ матриці під час обробки високохромистого білого чавуну.

Ключові слова: випробування на подряпини, високохромистий чавун, руйнування, механізм зношування, кБН.

Исследована износостойкость бельх чугунов с высоким содержанием хрома при использовании наноцарапание для понимания механизма износа при взаимодействии высокохромистого белого чугуна и режущего инструмента из сBN во время процесса обработки. Испытания царапанием проводили на приборе наноиндентирования с использованием алмазного индентора. Линейные многопроходные иарапины на одном и том же участке выполняли на предварительно изношенных поверхностях испытываемых материалов. Корреляиия сопротивления иарапанию и износа инструмента, измеренного при точении, показана при сравнении износа фланца и максимальной глубиной иарапины. Внешний вид режущей кромки на инструменте из сBN свидетельствует о том, что абразивный износ в основном связан с взаимодействием карбидов и матриць при обработке высокохромистого белого чугуна.

Ключевые слова: испытания на ияарапание, высокохромистый чугун, разрушение, механизм износа, $c B N$.

1. Tabrett C. P., Sare I. R., Ghomashchi M. R. Microstructure-property relationships in highchromium white iron alloys // Int. Mater. Rev. - 1996. - 41, N 2. - P. 59-82.

2. Zhou J. M., Andersson M. Machinability of abrasion resistance of cast iron with pcBN // Cutting Tools, Mater. Manufact. Proc. - 2008. - 23, N 5. - P. 506-512.

3. Kim C. K., Lee S., Jung J. Y. Effects of heat treatment on wear resistance and fracture toughness of duo-cast materials composed of high-chromium white cast iron and low-chromium steel // Metall. Mater. Trans. A. - 2006. - 37, N 3. - P. 33-643.

4. Bedolla Jacuinde A., Rainforth W. M. The wear behavior of high-chromium white cast irons as a function of silicon and Mischmetal content // Wear. - 2001. - 250, N 1-12. - P. 449-461.

5. Pinho K. F., Boher C., Scandian C. Effect of molybdenum and chromium contents on sliding wear of high-chromium white cast iron at high temperature // Lubrication Sci. - 2013. - 25, N 2. - P. 153-162.

6. ASTM A608/A608M-14, Standard Specification for Centrifugally Cast Iron-ChromiumNickel High-Alloy Tubing for Pressure Application at High Temperatures. - West Conshohocken, PA: ASTM International, 2012.

7. Metallography and Microstructures: ASM Handbook: Vol. 9 / Ed. G. F. Vander Voort. Ohio: ASM International, Materials Park , 2004. - 1184 p.

8. Chen L., Iyengar S., Zhou J. et al. Characterization of Microstructure and Mechanical Properties of High-Chromium Cast Irons Using SEM and Nanoindentation // J. Mater. Eng. Perform. - 2015. - 24, N 1. - P. 98-105.

9. Chen L., Zhou J., Bushlya V. et al. Performance assessment of pcBN and bcBN tools in machining of high-chromium white cast iron // Int. J. Adv. Manuf. Technol. - 2015. - 79, N 1-4. - P. 635-644.

10. Xu J., Yao $W$. Nano-scratch as a new tool for assessing the nano-tribological behavior of cement composite // Mater. Struct. - 2011. - 44, N 9. - P. 1703-1711.

Received 06.03.17 